\title{
Partial Least Square In Analyzing The Influence Of Service Quality, Facilities And Price On Customer
}

\section{Partial Least Square Dalam Menganalisis Pengaruh Kualitas Pelayanan, Fasilitas Dan Harga Terhadap Kepuasan Konsumen}

\author{
Mohammad Saefus Sholeh ${ }^{1}$, Ribangun Bamban Jakaria ${ }^{2}$ \\ \{saifuss97@gmail.com¹ ${ }^{1}$ ribangunz@umsida.ac.id ${ }^{2}$ \}
}

Program Studi Teknik Industri ${ }^{1}$, Fakultas Sains Dan Teknologi, Universitas Muhammadiyah Sidoarjo

\begin{abstract}
UD Barokah Tiga is a business that sells building materials and electric tools. The aim of this research is to measure how the influence of service quality, facilities and price affects customer satisfaction. The research that will be conducted here uses the Partial Least Square (PLS) method using the Warppls 7.0 software. The results of this study for service quality variables have a significant influence on customer satisfaction variables. Because it has a Pvalue of 0.001 from $<0.05$. For the value obtained X1 5,346 where > from 1.96 where for X1 has a significant value. The facility variable does not have a significant effect on the customer satisfaction variable. Because it has a P-value of 0.15 from <0.05. For the value obtained X2 1.054 where <from 1.96 where for X2 has an insignificant value. The price variable has a significant influence on the consumer satisfaction variable. Because it has a P-value of 0.001 from <0.05. For the value obtained X3 4,645 where> from 1.96 where for X3 has a significant value
\end{abstract}

Keywords - Customer Satisfaction; Service Quality; Facilities; Patrial Least Square Price

\begin{abstract}
Abstrak. UD Barokah Tiga adalah salah satu bisnis usaha yang menjual keperluan bahan bangunan dan alat-alat listrik. Tujuan dilakukanya penelitian dilakukan untuk mengukur bagaimana pengaruh kualitas pelayanan, fasilitas dan harga berpengaruh terhadap kepuasan konsumen. Dimana bisnis usaha tersebut begerak dalam jual beli bahan bangunan. Penelitian yang akan dilakukan disini menggunakan metode Partial Least Square (PLS) dengan menggunakan Sofware Warppls 7.0. Hasil penelitian untuk Variabel kualitas pelayanan memiliki pengaruh yang signifikan terhadapa variabel kepuasan konsumen. Karena memiliki nilai $P$-value 0,001 dari < 0,05. Untuk nilai yang diperoleh X1 5,346 dimana > dari 1,96 dimana untuk X1 memiliki nilai yang signifikan. Variabel fasilitas tidak memiliki pengaruh yang signifikan terhadapa variabel kepuasan konsumen di. Karena memiliki nilai P-value 0,15 dari <0,05. Untuk nilai yang diperoleh X2 1,054 dimana < dari 1,96 dimana untuk X2 memiliki nilai yang tidak signifikan. Variabel harga memiliki pengaruh yang signifikan terhadapa variabel kepuasan konsumen. Karena memiliki nilai P-value 0,001 dari <0,05. Untuk nilai yang diperoleh X3 4,645 dimana > dari 1,96 dimana untuk X3 memiliki nilai yang signifikan
\end{abstract}

Kata Kunci - Kepuasan Konsumen; Kualitas Pelayanan; Fasilitasl; Harga Patrial Least Square.

\section{PENDAHULUAN}

Pertumbuhan dunia bisnis semakin hari kian pesat, dalam bidang produk maupun jasa, beriringan dengan kemajuan teknologi dan informasi yang semakin canggih. Sehingga mampu memberikan alternative pelayanan kepada konsumen untuk memudahkanya memilih penawaran produk atau jasa. Dengan ini pemilik usaha harus peka terhadap pasar dan harus memaksimalkan fasilitas yang ada untuk memenuhi kebutuhan konsumen serta memberi kepuasan pelayanan, bahkan menjamin kepuasan pelangganya, agar tidak kalah bersaing di pasaran.

UD Barokah Tiga adalah salah satu bisnis usaha yang menjual keperluan bahan bangunan dan alat-alat listrik yang terletak di perum citra sentosa mandiri blok D-8, njambangan, candi, Kab. Sidoarjo. Mulai merasakan persaingan bisnis. Hal tersebut ditandai dengan berdirinya bisnis bahan bangunan serupa di lokasi sekitar. Dengan semakin banyaknya pelaku usaha yang sama, sebuah bisnis usaha harus mengatahui factor apa saja yang dapat mempengaruhi kepuasan konsumenya supaya bisa melakukan perbaikan serta inovasi baru yang diharapkan mampu meningkatkan kepuasan konsumen setelah melakukan belanja maupun transaksi di UD Barokah Tiga. Oleh karena iitu, peneliian akan dilakukan unttuk mengukur bagaimana penggaruh kualiitas pelayanan. harga dan fasilitas berpengaruh terhadap kepuasan konsumen. Pada peneliitian ini metode yang akan digunkan dalam memperoleh data adalah dengan metode Patrial Least Square (PLS) yang dimana hasilnya nanti diharpkan bisa digunakan untuk bahan evaluasi oleh pihak UD Barokah Tiga. 


\section{A. Kualitas pelyanan}

Kualitas pelayanan merupakan sebuah upaya pemenuhan kebutuhan dan keinginan konsumen dalam ketepatan penyampainya dalam mengimabangi harapan konsumen [1] Sedangkan dalam [2], Kualitas pelayanan adalah betuk dari aktifitas yang diberikan oleh suatu perusahaan agar mampu memenuhi harapan konsumen

\section{B. Pengertian fasilitas}

Fasilitas adalah sumber daya fisik yang harus ada sebelum suatu jasa dapat ditawarkan kepada konsumen. Karena suatu bentuk jasa tidak dapat dilihat, tidak bisa di cium dan tidak bisa diraba maka aspek wujud fisik menjadi penting sebagai ukuran pelayanan [7]

\section{Pengertian harga}

Harga juga adalah sejumlah uang yang ditukarkan untuk sebuah produk atau jasa. Lebih jauh lagi harga adalah jumlah dari seluruh nilai yang konsumen tukarkan untuk jumlah manfaat dengan memiliki atau menggunakan suatu jasa. [3]

\section{Pengertian kepuasan konsumen}

kepuasan adalah kesan kerja dan sebuah harapan, Banyaknya menitik beratkan pada kepuasan konsumen yang tinggi karena hal ini akan mengikat konsumen karena merasa puas akan pelayanan yang didapat [4] pada dasarnya definisi kepuasan pelanggan iyalah mencakup perbandingan tingkat hasil atau kinerja yang dirasakan [10]

\section{E. Partial least square (pls)}

Partial Least Square (PLS) adalah sebuah metode yang mampu menciotakan dan membangun sebuah model menggunakan pendekatan yang berorientasi pada prediksi, Partial least square (PLS) memiliki sebuah asumsi data penelitian bebas distribusi [9] PLS dapat menganalisis sekaligus variabel laten yang dibentuk dengan indicator reflektif dan indicator formatif ukuran sampel dalam PLS ditentukan dengan salah satu atura sebagai berikut [5]

\section{F. Variabel}

Variabel dapat juga dibagi sebagai variabel tidak bebas dan variabel bebas . Apabila ada hubungan antara dua variabel. Misalnya antara variabel $\mathrm{Y}$ dan variabel $\mathrm{X}$, dan jika variabel $\mathrm{Y}$ disebabkan oleh variabel $\mathrm{X}$, maka variabel $\mathrm{Y}$ adalah variabel tidak bebas dan variabel $\mathrm{X}$ adalah variabel bebas. [6]

\section{G. Populasi dan sampel}

Populasi merupakan sebuah wilayah generelasi yang terdiri dari beberapa subjek atau objek yang memiliki kualitas serta karateristik tertentu yang telah ditetapkan oleh penelitian ini untuk dipelajari dan kemudian diambil kesimpulanya. sampel adalah bagian dari jumlah dan karateristik yang dimiliki oleh populasi tersebut. Ukuran sampel yang layak dalam penelitian adalah 30 sampai dengan 500. [8]

\section{METODE}

Dalam tahap ini pengolahan data dilakukan dengan beberapa proses menggunakan software Microsoft Excel 2007 dan WarpPLS 7.0 sebagai berikut.

1. Evaluasi model pengukuran atau outer model

Evaluasi model pengukuran atau outer model dilakukan untuk menilai validitas dan reliabilitas dari indicator pembentuk konstruk laten. Pengujian yang dilakukan dalam outer model adalah

a. Convergent Validity

b. Discriminant Validity

c. Composite Reliablity

2. Evaluasi model structural atau inner model

Evaluasi model structural atau inner model meliputi uji kecocokan model fit terdapat tiga indeks pengujian.

a. Average path coefficient (APC)

b. Average R-square (ARS)

c. average varians factor (AVIF)

3. Uji Hipotesis

Setellah melalukan evaluasi outer model dan inner model selanjutnya adalah melakukn penguijian hipotesis. Uji hipotesiis digunakan untuk menjellaskan arah hubungan antara variabel independent dan variable dependenya.

Pemaparan metoda penelitian harus detail, utamanya mengenai metoda apa yang digunakan dan data-data apa yang digunakan dari suatu penelitian. 


\section{HASIL DAN PEMBAHASAN}

\section{A. Converegent validity}

Model pemgukuran ini dapat diliihat dari korellasi antara skor indicator dengan skor konstruknya (Loading Factor) dengan nilai loading factor dari setiap indicator. Ada dua kriteria untuk menfetahui apakah Outer model memenuhi syarat validitas konvergent pertama nilai loading factor harus diatas 0,70 dan nilai p-signifikan $<0,05$. Namun apabila ada nilai loading antara 0,40-0,70 sebaiknya kita melihat nilai batasan Avarage variance extracted (AVE) harus memenuhi batasan diatas 0,50 .

Tabel 1 Combined loadings and cross-loadings

\begin{tabular}{|c|c|c|c|c|c|c|c|}
\hline \multicolumn{8}{|c|}{ Combined loadings and cross-loadings $*$} \\
\hline & $\mathrm{X} 1$ & $\mathrm{X} 2$ & $\mathrm{X} 3$ & $\mathrm{Y}$ & Type (a & $S E$ & $P$ value \\
\hline $\mathrm{X} 1.1$ & $(0.749)$ & 0.085 & 0.076 & -0.202 & Refect & 0.122 & $<0.001$ \\
\hline $\mathrm{X} 1.2$ & $(0.813)$ & -0.012 & -0.006 & -0.041 & Refect & 0.096 & $<0.001$ \\
\hline $\mathrm{X} 1.3$ & $(0.682)$ & -0.019 & -0.089 & 0.183 & Refect & 0.090 & $<0.001$ \\
\hline $\mathrm{X} 1.4$ & $(0.681)$ & -0.007 & -0.01 & -0.025 & Refect & 0.120 & $<0.001$ \\
\hline $\mathrm{X} 1.5$ & $(0.710)$ & -0.035 & 0.038 & 0.054 & Refect & 0.116 & $<0.001$ \\
\hline $\mathrm{X} 2.1$ & 0.146 & $(0.650)$ & -0.076 & 0.096 & Refect & 0.133 & $<0.001$ \\
\hline $\mathrm{X} 2.2$ & 0.118 & $(0.806)$ & 0.005 & -0.135 & Refect & 0.192 & $<0.001$ \\
\hline $\mathrm{X} 2.3$ & -0.134 & $(0.882)$ & 0.048 & 0.031 & Refect & 0.159 & $<0.001$ \\
\hline X2.4 & -0.061 & $(0.770)$ & -0.046 & 0.001 & Refect & 0.186 & $<0.001$ \\
\hline $\mathrm{X} 2.5$ & -0.135 & $(0.625)$ & 0.131 & -0.066 & Refect & 0.234 & 0.004 \\
\hline X3.1 & 0.104 & 0.009 & $(0.801)$ & -0.104 & Refect & 0.116 & $<0.001$ \\
\hline X3.2 & 0.037 & -0.142 & $(0.630)$ & -0.150 & Refect & 0.123 & $<0.001$ \\
\hline X3.3 & -0.074 & -0.074 & $(0.808)$ & 0.066 & Refect & 0.129 & $<0.001$ \\
\hline X3.4 & -0.042 & 0.128 & $(0.834)$ & 0.106 & Refect & 0.109 & $<0.001$ \\
\hline Y1 & -0.083 & 0.046 & 0.022 & $(0.703)$ & Refect & 0.092 & $<0.001$ \\
\hline Y2 & 0.233 & -0.182 & 0.087 & $(0.735)$ & Refect & 0.155 & $<0.001$ \\
\hline $\mathrm{Y} 3$ & -0.048 & -0.005 & -0.110 & $(0.722)$ & Refect & 0.125 & $<0.001$ \\
\hline Y4 & -0.092 & 0.090 & 0.035 & $(0.765)$ & Refect & 0.111 & $<0.001$ \\
\hline Y5 & -0.041 & 0.070 & -0.057 & (0.711) & Refect & 0.083 & $<0.001$ \\
\hline
\end{tabular}

\section{B. Discriminant validity}

Suau modell mempuyai validiitas discriminant yang cukup besar jika akar AVE untuk setiap construk lebih besar daripada kolerasi antar setiap construk lainya dalam model. Dari tabel dibawah nilai akar X1 $(0,729)$ X2 $(0,753)$ X3 $(0,773)$ Dan Y $(0,728)$ Dari hasil tabel dibawah menunjukan bahwa nilai akar AVE untuk ke empat konstruk lebih besar daripada koleras antar konstruk ke atas dan kebawah. Berikut adalah nilai akar AVE dan kolerasi variable laten Tabel 2 Correlations among l.vs. with sq. rts. of AVEs

\section{Composity reability}

\begin{tabular}{ccccc}
\hline \multicolumn{5}{c}{ Correlations among l.vs. with sq. rts. of AVEs } \\
\hline & $\mathrm{X} 1$ & $\mathrm{X} 2$ & $\mathrm{X} 3$ & $\mathrm{Y}$ \\
$\mathrm{X} 1$ & $(0.729)$ & 0.190 & 0.208 & 0.592 \\
$\mathrm{X} 2$ & 0.190 & $(0.753)$ & 0.283 & 0.292 \\
$\mathrm{X} 3$ & 0.208 & 0.283 & $(0.773)$ & $0.48[3] 5$ \\
$\mathrm{Y}$ & 0.592 & 0.292 & 0.485 & $(0.728)$ \\
\hline
\end{tabular}

Selanjutnya untuk pengejuian yang dapat dilakukan adallah uji reabilitas construk yang dapat diiukur menggunakan dua kriteria yaitu Composity Reability dan Cronbach Alpha suatu construk diyatakan reliable jika nilai Composity Reability $>070$. dan berikut ini hasil output laten variable coefisien 
Procedia of Engineering and Life Science Vol. 1. No. 2 Juni 2021

Seminar Nasional \& Call Paper Fakultas Sains dan Teknologi (SENASAINS 2nd)

Universitas Muhammadiyah Sidoarjo

\begin{tabular}{ccccc}
\hline \multicolumn{5}{c}{ Latent Variable Coefficients } \\
\hline & $\mathrm{X} 1$ & $\mathrm{X} 2$ & $\mathrm{X} 3$ & $\mathrm{Y}$ \\
\hline $\begin{array}{c}\text { R-square } \\
\text { Adj. } \text {-squared }\end{array}$ & & & & 0,495 \\
$\begin{array}{c}\text { Composite } \\
\text { Reliab. }\end{array}$ & 0,849 & 0,866 & 0,854 & 0,480 \\
$\begin{array}{c}\text { Cronbach's } \\
\text { alpha }\end{array}$ & 0,778 & 0,809 & 0,776 & 0,849 \\
Avg.var.extrac. & 0,531 & 0,567 & 0,597 & 0,529 \\
Full colin. VIF & 1,561 & 1,127 & 1,365 & 1,982 \\
Q-squared & & & & 0,501 \\
Min & $-3,368$ & $-3,454$ & $-3,965$ & $-3,905$ \\
Max & 1,640 & 1,332 & 1,886 & 1,807 \\
Median & 0,056 & 0,102 & 0,183 & 0,060 \\
Mode & $-0,177$ & $-0,184$ & 0,291 & 0,060 \\
Skewness & $-1,275$ & $-1,307$ & $-1,265$ & $-1,245$ \\
Exc. Kurtosis & 2,127 & 2,519 & 2,562 & 2,464 \\
Unimodal- $R S$ & Yes & Yes & Yes & Yes \\
Unimodal- & Yes & Yes & Yes & Yes \\
KMV & No & No & No & No \\
Normal-JB & No & No & No & No \\
Normal-RJB & No & View & View & View \\
Histrogram & View & & & \\
\hline
\end{tabular}

\section{Evaluasi pengukuran iner model}

Untuk Tahapan selanjutnya adalah pengukuran evaluai structural Inner Model, meliputi tentang uji kecocokan model model fit, path coefisien. Dalam uji kecocokan model fit, path coefisien ada tiga indek penguijian, yaitu Avarage Path Coeficient (APC), Avarage R-Square (ARS) dan Avarage variians Factor (AVIF) dengan kreterian P-Value $<0,05$ dan AVIF lebih kecil dari 5.

Tabel 4 Model fit and quality indices

Model fit and quality indices

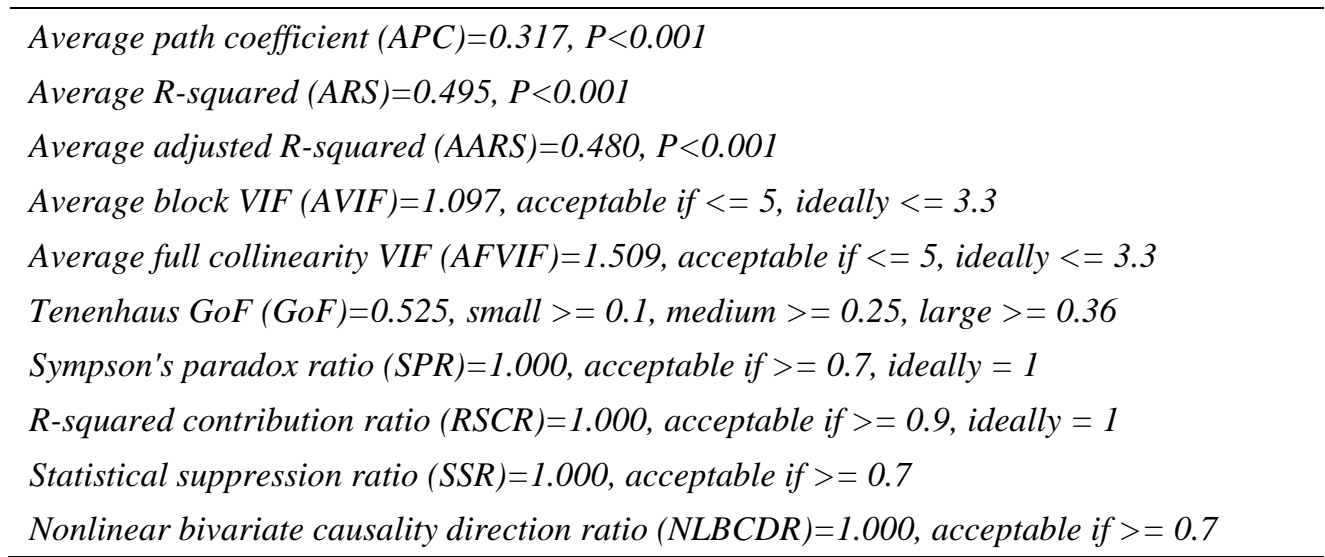

\section{E. Pengujian hipotesis pertama}

Berikut ini adalah hasil uji hipotesis H1 kualitas pelayanan diuraikan lebih lanjut sebagai berikut.

a Hipotesis

Ho= kuaitas pelayanan tidak berpengaruh terhadap kepuasan konsumen 
b $\mathrm{Ha}=$ kuaitas pelayanan berpengaruh positif terhadap kepuasan konsumen

Dasar Pengambilan Keputusan

$P$-Value $<0,05(\alpha=5 \%)$, Maka Hipotesis diterima

$P$-Value $>0,05(\alpha=5 \%)$, Maka Hipotesis ditolak

c Keputusan

$P$-Value $=0,001(<0,05)$ maka $\mathrm{H} 1$ diterima

d Kesimpulan

Variabel kualitas pelayaan memiiliki pengaruh yang signiifikan terhadapa variable kepuasan konsumen di UD Barokah Tiga. Karena memiliki nilai $P$-value 0,001 dari 0,05 sebagai batas tingkat signifikan. Variable kualitas pelayanan juga memiliki pengaruh positif terhadap variable kepuasan konsumen yang dapat diamati dari nilai koefisiien jalur yang bernilai positif 0,50. Angka ini menunjukan bahwa jika terjadi peniingkatan penilaian terhadap kualitas pelayanan di UD Barokah, maka kepuasan konsumen akan meningkat sebesar 0,50 dan begitu sebaliknya, setiap terjadi penurunan kuallitas pelayanan, maka kepuasan konsumen akan menurun sebesar 0,50.

\section{F. Pengujian hipotesis kedua}

Berikut ini adalah hasil uji hipotesis H2 Fasilitas diuraikan lebih lanjut sebagai berikut.

a. Hipotesis

$\mathrm{Ho}=$ fasilitas tidak berpengaruh terhadap kepuasan konsumen

$\mathrm{Ha}=$ fasilitas berpengaruh positif terhadap kepuasan konsumen

b. Dasar Pengambilan Keputusan

$P$-Value $<0,05(\alpha=5 \%)$, Maka Hipotesis diterima

$P$-Value $>0,05(\alpha=5 \%)$, Maka Hipotesis ditolak

c. Keputusan

$P$-Value $=0,15(>0,05)$ maka $\mathrm{H} 2$ ditolak

d. Kesimpulan

Variabel fasilitas tidak memiliki pengaruh yang signifikan terhadapa variabel kepuasan konsumen di UD Barokah Tiga. Karena memiliki nilai $P$-value 0,15 dari 0,05 sebagai batas tingkat signifikan. fasilitas juga memiliki pengaruh positif terhadap variabel kepuasan konsumen yang dapat diiamati dari nilai koefiisien jalur yang berniilai positif 0,10. Angka ini menunjukan bahwa jika terjadi peningkatan penilaian terhadap fasilitas di UD Barokah, maka kepuasan konsumen akan meningkat sebesar 0,10 dan begitu sebaliknya, setiap terjadi penurunan fasilitas, maka kepuasan konsumen akan menurun sebesar 0,10.

\section{G. Pengujian Hipotesis Ketiga}

Berikut ini adalah hasil uji hipotesis H3 Harga diuraikan lebih lanjut sebagai berikut.

a. Hipotesis

Ho= Harga tidak berpengaruh terhadap kepuasan konsumen

$\mathrm{Ha}=$ Harga berpengaruh positif terhadap kepuasan konsumen

b. Dasar Pengambilan Keputusan

$P$-Value $<0,05(\alpha=5 \%)$, Maka Hipotesis diterima

$P$-Value $>0,05(\alpha=5 \%)$, Maka Hipotesis ditolak

c. Keputusan

$P$-Value $=0,001(<0,05)$ maka H3 diterima

d. Kesimpulan

Variabel harga memilliki pengaruh yang signiifikan terhadapa variabel kepuasan konsumen di UD Barokah Tiga. Karena memiliki nilai $P$-value 0,001 dari 0,05 sebagai batas tingkat signifikan. Variable harga juga memiiliki pengaruh positif terhadap variable kepuasan konsumen yang dapat diamati dari nilai koefisiien jalur yang bernilai positif 0,35. Angka ini menunjukan bahwa jika terjadi peningkatan penilaian terhadap harga di UD Barokah, maka kepuasan konsumen akan meningkat sebesar 0,35 dan begitu seballiknya, setiap terjadi penurunan kualitas pelayanan, maka kepuasan konsumen akan menurun sebesar 0,35.

\section{KESIMPULAN}

Berdasarkan hasil pengujian dan pembahasan yang telah dilakukan dalam bab 4 maka dapat disimpulkan sebagao berikut. Variabel kualitas pelayanan memiliki pengaruh yang signifikan terhadapa variabel kepuasan konsumen di UD Barokah Tiga. Karena memiliki nilai $P$-value 0,001 dari < 0,05. Untuk nilai yang diperoleh X1 5,346 dimana > dari 1,96 dimana untuk X1 memiliki nilai yang signifikan Dengan demikian tingkat kualitas pelayanan dalam sebuah kegiatan Sehari hari di UD Barokah Tiga dapat mempengaruhi Kepuasan konsumen yang sedang berkunjung di UD Barokah tiga. Variable fasilitas tidak memilliki pengaruh yang signifikan terhadapa variabel 
kepuasan konsumen di UD Barokah Tiga. Karena memiliki nilai $P$-value 0,15 dari $<0,05$. Untuk nilai yang diperoleh X2 1,054 dimana < dari 1,96 dimana untuk X2 memiliki nilai yang tidak signifikan Dengan demikian tingkat fasilitas yang ada dalam lingkungan di UD Barokah Tiga tidak mempengaruhi Kepuasan konsumen yang sedang berkunjung di UD Barokah tiga.Variabel harga memilliki pengaruh yang signifiikan terhadapa variabel kepuasan konsumen di UD Barokah Tiga. Karena memiliki nilai $P$-value 0,001 dari <0,05. Untuk nilai yang diperoleh X3 4,645 dimana > dari 1,96 dimana untuk X1 memiliki nilai yang signifikan Dengan demikian tingkat harga yang ditetapkan dalam setiap transaksi dengan konsumen yang berkunjung mungkin bisa terlalu mahal atau memang tempat dimana UD Barokah tiga mendapatkan barang terlalu mahal.

\section{UCAPAN TERIMAKASIH}

Ucapan terima kasih terutama ditujukan kepada pemberi dosen pembibing dan rekan rekan yang membantu saya menyelesaikan tugas akhir pelaksanaan penelitian.

\section{REFRENSI}

[1] J. E. Panjaitan and A. L. Yuliati, "Pengaruh Kualitas Pelayanan Terhadap Kepuasan Pelanggan Pada JNE Cabang Bandung [The Influence of Service Quality on Customer Satisfaction at JNE Branch in Bandung]," DeReMa (Development Res. Manag. J. Manaj., vol. 11, no. 2, p. 265, 2016, doi: 10.19166/derema.v11i2.197.

[2] S. Putro, H. Semuel, and R. Brahmana, "Pengaruh Kualitas Layanan Dan Kualitas Produk Terhadap Kepuasan Pelanggan Dan Loyalitas Konsumen Restoran Happy Garden Surabaya,” J. Manaj. Pemasar., vol. 2, no. 1, pp. 1-9, 2014.

[3] Munawir, "Pengaruh Kualitas Pelayanan dan Fasilitas Terhadap Kepuasan Konsumen Foto Copy Awy Comp di Pondok Pesantren Darussalam Blokagung Tegalsari Banyuwangi,” Huk. Islam. Dan Bisnis, vol. 4, no. 2, pp. 204-215, 2018.

[4] E. Cahyaningrum and A. Hoyyi, "ANALISA FAKTOR-FAKTOR YANG MEMPENGARUHI KINERJA PERUSAHAAN MENGGUNAKAN PENDEKATAN PARTIAL LEAST SQUARE (Studi Kasus pada PT. Telkom Indonesia Divisi Regional Jawa Tengah-DIY dan Wilayah Telekomunikasi Semarang)," vol. 4, no. 2004, pp. 805-814, 2015.

[5] A. S. Insani, A. Hoyyi, and R. Rahmawati, "Analisis Faktor-Faktor Yang Mempengaruhi Kepuasan Mahasiswa dalam Pemilihan Jurusan Menggunakan Structural Equation Modeling (SEM),”J. Gaussian, vol. 3, no. 4, pp. 537-546, 2014.

[6] E. Natalia, A. Hoyyi, and R. Santoso, "Analisis Kepuasan Masyarakat Terhadappelayanan Publik Menggunakan Pendekatan Partial Least Square (PLS) (Studi Kasus: Badan Arsip dan Perpustakaan Daerah Provinsi Jawa Tengah)," J. Gaussian, vol. 6, no. 3, pp. 313-323, 2017.

[7] N. Srijani and A. S. Hidayat, "Pengaruh Fasilitas Terhadap Kepuasan Pelanggan Di Aston Madiun Hotel \& Conference Center," Wiga J. Penelit. Ilmu Ekon., vol. 7, no. 1, pp. 31-38, 2018, doi: 10.30741/wiga.v7i1.336.

[8] L. L. Salomon and M. A. Saryatmo, "PENGARUH DIMENSI KUALITAS TERHADAP KEPUASAN PELANGGAN DUNIA FANTASI PT. PJA Lithrone Laricha Salomon, M. Agung Saryatmo dan Stephanie Meliana," vol. 3, no. 1, pp. 25-32, 2015.

[9] N. M. Shandyastini and K. D. P. Novianti, "Analisis E-Learning STMIK Stikom Bali Menggunakan Technology Acceptance Model,” J. TEKNOIF, vol. 4, no. 2, pp. 1-6, 2016.

[10] S. Zulaicha and R. Irawati, "Pengaruh Produk Dan Harga Terhadap Keputusan Pembelian Konsumen Di Morning Bakery Batam,” Inovbiz J. Inov. Bisnis, vol. 4, no. 2, p. 123, 2016, doi: 10.35314/inovbiz.v4i2.76. 